\title{
Differences in Stage of Integration between Business Planning and Information Systems Planning according to Value Configurations
}

\author{
Petter Gottschalk and Hans Solli-Sæther \\ Norwegian School of Management BI, Sandvika, Norway
}

petter.gottschalk@bi.no, hans.soli-sather@bi.no

\begin{abstract}
Integration between business planning and information systems (IS) planning is considered an important enabler of business - IS alignment. A content analysis of IS plans was conducted to identify stages of integration between business and IS planning. The companies studied were also classified according to value configurations and eras of IS growth. Empirical results indicate that companies classified as value networks are at a higher stage of integration than value shops and chains probably because they are in the network era rather than the data processing or information technology eras.
\end{abstract}

Keywords: integration mechanisms, value configurations, the role of IS, IS era of growth, strategic IS plans, content analysis.

\section{Introduction}

Today many companies make large investments in information systems (IS) (Earl and Feeny 1994). Yet executives often question the business-IS alignment, namely whether these investments support their strategic objectives or whether opportunities to exploit IS for competitive advantage are being overlooked (Henderson and Venkatraman 1993). There are both enablers and inhibitors of business-IS alignment (Luftman, Papp et al. 1999) and one area considered important for improved alignment is integration of strategic business and IS planning (Teo and Ang 1999).

This research is concerned with how stages of integration between strategic business and IS planning are related to different value configurations and eras of IS growth. The research question can be stated as: What differences in the stages of integration between business and IS planning are found according to companies' value configuration and are

Material published as part of this journal, either on-line or in print, is copyrighted by the publisher of Informing Science. Permission to make digital or paper copy of part or all of these works for personal or classroom use is granted without fee provided that the copies are not made or distributed for profit or commercial advantage AND that copies 1) bear this notice in full and 2) give the full citation on the first page. It is permissible to abstract these works so long as credit is given. To copy in all other cases or to republish or to post on a server or to redistribute to lists requires specific permission and payment of a fee. Contact Editor@inform.nu to request redistribution permission. these differences affected by their era of IS growth?

The word planning is used in the literature in many and various meanings: as future thinking, as controlling the future, as decision making, as integrated decision making, and as a formalized procedure to produce an articulated result, in the form of an integrated system of decisions (Mintzberg 1994). In this paper, a planning approach is defined as strategic decision making through a rational process that allows managers to formulate and document strategies. The aim of this study was not to do process research, but rather to investigate how IS planning (ISP) is integrated with business planning (BP).

Value configuration can be defined as an organization of activities, resources, and technologies, in order to create firm level competitive advantage. Our assumption is that there exist three basic value creation logics. Based on this assumption, this paper discusses differences in stages of integration between business and IS planning according to companies' value configurations, and attempts to relate these differences to eras of IS growth.

\section{Integration mechanisms}

Although no precise definition of strategic alignment of business and IS strategies has gained widespread acceptance, many authors share a similar general interpretation of the term. Strategic alignment is said to be present when: 
Differences in Stage of Integration

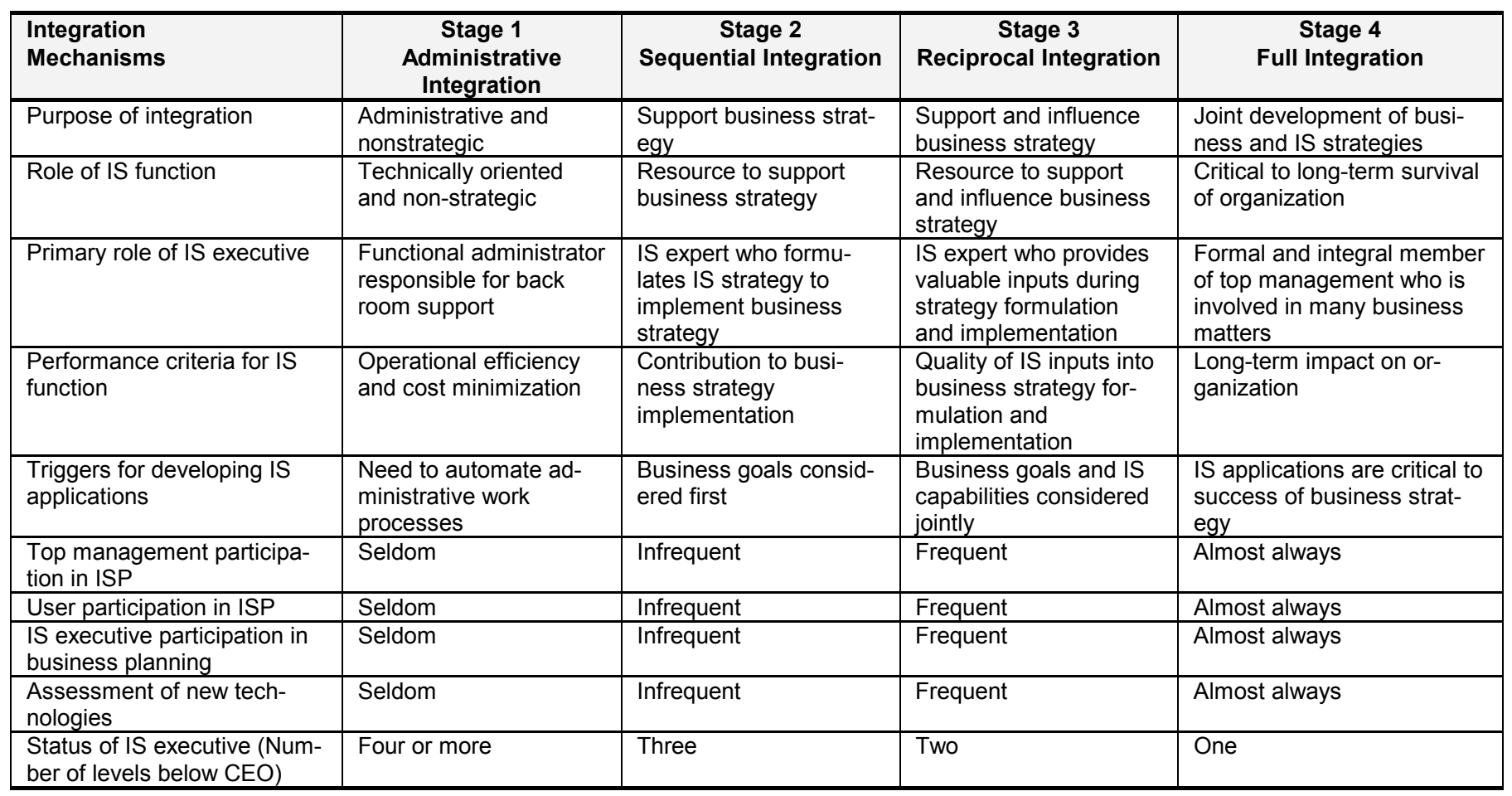

Table 1: Stages of integration (King and Teo 1997).

i) business strategies are enabled, supported, and stimulated by information strategies (Broadbent and Weill 1993);

ii) the goals and activities of the business are in harmony with the information systems that support them (Woolfe 1993);

iii) information systems support organizational goals and activities at every level (Lederer and Mendelow 1989); and

iv) choices within content and process dimensions of IS planning are mutually supportive and the two dimensions themselves are harmonized in a manner that is consistent with competitive strategy (Das, Zahra et al. 1991).

Integration between business planning and information systems planning is one important enabler of business-IS alignment (Teo and King 1997; Luftman, Papp et al. 1999; Teo and Ang 1999). Teo and King (1997) found a significant positive relationship between the level of business and IS planning integration and the extent of information systems contribution to organizational performance. King and Teo
(1997) have suggested a stages of integration model for the evolution of integration between strategic business and IS planning. The first stage is a separate planning with administrative integration characterized by the integration mechanisms in Table 1, such as a technically oriented and non-strategic role of the IS function. The second is a one-way linked planning with sequential integration characterized by integration mechanisms in Table 1, such as performance criteria of business strategy contribution. The third is a two-way linked planning with reciprocal integration such as frequent IS executive participation in business planning. The fourth is joint planning with full integration.

\section{Value configurations}

Thompson (1967) describes three types of technology, which are important to the understanding of rationality in organizations - long-linked technology, mediating technology, and intensive technology. The three technology types have distinctive value creation logic. Where as long-linked technologies focus on transformation of inputs into outputs, mediating and intensive technologies focus respectively on linking of customers and solving customer problems. 


\begin{tabular}{|l|l|l|l|}
\hline & Chain & Shop & Network \\
\hline Value creation logic & $\begin{array}{l}\text { Transformation of input into } \\
\text { output }\end{array}$ & $\begin{array}{l}\text { (Re) solving customer prob- } \\
\text { lems }\end{array}$ & Linking customers \\
\hline Primary technology & Long-linked & Intensive & Mediating \\
\hline Primary activities & $\begin{array}{l}\text { Inbound logistics, operations, } \\
\text { outbound logistics, market- } \\
\text { ing, service }\end{array}$ & $\begin{array}{l}\text { Problem-finding, problem } \\
\text { solving, choice, execution, } \\
\text { control/evaluation }\end{array}$ & $\begin{array}{l}\text { Network promotion and con- } \\
\text { tract management, service } \\
\text { provisioning, infrastructure } \\
\text { operation }\end{array}$ \\
\hline $\begin{array}{l}\text { Main interactivity relation- } \\
\text { ship logic }\end{array}$ & Sequential & Cyclic, spiraling & Simultaneous, parallel \\
\hline $\begin{array}{l}\text { Primary activity interde- } \\
\text { pendence }\end{array}$ & Pooled, sequential & Pooled, sequential, reciprocal & Pooled, reciprocal \\
\hline Key cost drivers & Scale, capacity utilization & Reputation & Scale, capacity utilization \\
\hline Key value drivers & & Referred shops & Scale, capacity utilization \\
\hline $\begin{array}{l}\text { Business value system struc- } \\
\text { ture }\end{array}$ & Interlinked chains & $\begin{array}{l}\text { Layered and interconnected } \\
\text { networks }\end{array}$ \\
\hline
\end{tabular}

Table 2: Characteristics of the three value configurations (Stabell and Fjeldstad 1998).

Porter (1985) addresses the interplay between the cost or differentiation types of competitive advantage and the scope of the firm's activities. As a general framework for systematically examining the activities of the firm, he introduces the concept of the value chain, which models a long-linked technology quite well. But, differences in value creation logic indicate that Porter's value chain may not be optimal as an analytical framework for all kinds of businesses.

Stabell and Fjeldstad (1998) introduce the value shop and the value network as alternative value configurations. The analytical framework of the value shop relies on an intensive technology to solve a customer or client problem. Selection, combination, and order of application of resources and activities vary according to the problem at hand. The analytical framework of the value network relies on a mediating technology to link clients or customers who are or wish to be interdependent. The mediating technology facilitates exchange relationships among customers distributed in time and space.

The first value configuration in Table 2 is concerned with characteristics of the chain. Every firm's value chain is composed of nine generic categories of activities, which are linked together in a characteristic way. Five primary activities are inbound logistics, operations, outbound logistics, marketing and sales, and services. All basic activities interact with four support activities: procurement, technology development, human resource management, and firm infrastructure. These activities are called the value activities and they have a sequential nature. The main drivers of competitive advantage are scale and capacity utilization, as margin is the difference between the total value and the collective costs of performing the value activities.
The second configuration in Table 2 is concerned with shops. The value shop has five generic categories of primary activities are problem finding and acquisition, problem solving, choice, execution, and control/evaluation. Support activities are less important in this setting because, to a large extent, they are co-performed with the primary activities. Typically, there is a cyclical interactivity between primary activities. Evaluation at the end of one problem-solving circle can lead to the problem-finding activity of a new problem-solving circle. Competitive advantage follows from the ability to solve customer's problem (reputation signals this value). This often means specialization in problems and solution technologies.

The third and final configuration in Table 2 is network. The primary activities of the value network are network promotion and contract management, service provisioning, and network infrastructure operation. Contract and contracting services vary, depending on factors like time, volume, quality of service, and the number of connections established. Service provisioning depends on what kind of link the company mediates. Activities associated with operation of infrastructure depend on the nature of the infrastructure. Support activities are firm infrastructure, human resource management, technology development, and procurement. The three primary activity categories overlap in order to underline the concurrent interactivity relationship across primary activity categories. The lack of direction of value creation, where no arrow identifies the final customer, underlines that the work creates value by mediating between customers. 


\section{Eras of IS growth}

Nolan's (1973) theory, perhaps the best-known and most widely cited model of IS evolution of in organizations, provides an insight into the way IS evolves in organizations and offers IS management the possibility of managing this complex phenomenon. The model describing the theory does not appear in the literature as a single model, but rather as a number of versions of the same model, which have evolved over time (Khandelwal and Ferguson 1999). For example, the model has been expanded in the form of three S-curves, each curve describing an era, with a discontinuity between the preceding and the following eras. The three eras are identified as data processing (DP) era, information technology (IT) era, and network (NW) era. These eras are themselves subdivided into three phases each as shown in Table 3. The curves represent both the growth of the IS and the organization's learning experience as IS progresses through these eras. Each era is characterized by a period of evolution, followed by a period of stability, ending with a period of discontinuity before the start of the next era. The discontinuity is more a revolution rather than an evolutionary transition. For example, the transition from DP era to IT era is characterized by technological discontinuities in the form of personal computers, data communication networks, and robotics, while the transition from IT era to NW era is characterized by business discontinuities in the form of strategic alliances with customers and suppliers, access to external data, and outsourcing.

\begin{tabular}{|l|c|l|}
\hline Era & Phase & Characteristic \\
\hline Data Processing (DP) & 1 & Initiation \\
& 2 & Contagion \\
& 3 & Control \\
\hline Information technology & 4 & Integration \\
(IT) & 5 & Architecture \\
& 6 & Demassing \\
\hline Network (NW) & 7 & Functional infrastructure \\
& 8 & Tailored growth \\
& 9 & Rapid reaction \\
\hline
\end{tabular}

Table 3: Eras and phases of IS growth.

\section{Propositions}

In our research we want to link value configurations (Stabell and Fjeldstad 1998) and eras of IS growth (Khandelwal and Ferguson 1999) to explain stages of integration between BP and ISP (King and Teo 1997). The role of IS in value networks is mediating (see Table 2) and this role belongs to the NW era (see Table 3). The role of IS in value chains is longlinked (see Table 2) and this role belongs to the IT era (see Table 3). The role of IS in value shops is intensive (see Table 2 ) and this role belongs to the DP era. In the DP era, adminis- trative integration will be most common. In the IT era, sequential integration will be most common. In the NW era, reciprocal and full integration will be most common. Hence,

Proposition 1: Value networks are more likely than value chains and value shops to facilitate integration between business planning and IS planning.

Proposition 2: Value chains are more likely than value shops to facilitate integration between business planning and IS planning.

\section{Methodology}

The research question in this research is: "What differences in the stages of integration between business and IS planning are found according to companies' value configuration and are these differences affected by their era of IS growth?" The form of the research question is "what" which can be explored using the research strategy of documentation and archival analysis (Yin 1994). Strengths of this form of evidence collection are stability (can be reviewed repeatedly),

unobtrusiveness (not created as a result of the study), exact (contains exact names, references, and details), and coverage (all planning aspects). Specifically, this research applied content analysis, which is a research technique for making inferences by systematically and objectively identifying specified characteristics of messages (Riffe and Freitag 1997; Naccarato and Neuendorf 1998).

According to Weber (1990), content analysis is a research method that uses a set of procedures to make valid inferences from textual material and to reduce it to more relevant and manageable bits of data. A central idea in content analysis is that many words of the text are classified into many fewer content categories. The central problems of content analysis originate mainly in the data-reduction process. One set of problems concerns the consistency or reliability of text classification. Classification by multiple human coders permits quantitative assessment of achieved reliability. A much more difficult set of problems concerns the validity of variables based on content classification. A content analysis variable is valid to the extent that it measures the construct the investigator intends it to measure (Weber 1990).

According to Riffe and Freitag (1997), seven characteristics of content analyses distinguish poor studies from excellent studies. First, an explicit theoretical framework is needed. In this research, stages theory is the framework to study integration mechanisms (King and Teo 1997). Second, hypotheses or research questions are needed. In this research, the research question "what" is concerned with evidence of integration. Third, other research methods should also be applied. In this 
research, this was not done. Fourth, extra-media data should be incorporated. This was not possible in the research because such data were not available to the researchers. Fifth, intercoder reliability should be reported. In this research, two researchers coded the content construct of integration. Sixth, reliability based on random sample of coded content was not relevant in this research. Finally, presentations of only descriptive statistics should be avoided.

In this research, content analysis was applied using key words (Crouch and Basch 1997; Beattie and Sohal 1999) for coding (Miles and Huberman 1994). Key words concerning integration were treated as content constructs (Naccarato and Neuendorf 1998). The model of analysis may be classified as hermeneutics. According to Lee (1991), the motivating question in hermeneutics is: after a writer has implanted certain meanings in a text, how might readers of the text, especially those who belong to a different time and culture from the writer of the text, proceed to interpret the text for the meanings originally implanted in it, where other portions of the text itself are the primary, or sometimes the only, cross-referencing tools available? It can be argued that the meaning of a particular passage in a text as interpreted by the reader is related inextricably to the meanings of all other passages in the same text. In this research, manual inspection of all documents was performed to avoid this pitfall.

Codes are tags or labels for assigning units of meaning to the descriptive information in collected information (Miles and Huberman 1994). Codes usually are attached to words, phrases, sentences, or whole paragraphs, connected or unconnected to a specific setting. In this research, key words were derived from attributes in Table 1 and Table 2.

The content analysis is designed to yield numerical data in terms of frequencies. This kind of quantification has the advantage that statistical methods provide a powerful set of tools not only for precise and parsimonious summary of findings, but also for improving the quality of interpretation and inference (Holsti 1969). According to Krippendorff (1980), by far the most common form of representation of data, serving primarily the summarizing function of analysis, is in terms of frequencies and their associations and correlation with other variables.

\section{Sample}

A letter asking for a copy of the IS strategy was sent to 408 IS managers in Norway in 1999. We received 41 IS strategies in the mail (both paper mail and email), while we got email messages from 15 organizations telling us that they were unable to send us their strategy for various reasons. Organization size ranged from 170 to 30000 employees. One plan was written in 1993, three in 1995, one in 1996, seven in 1997, nineteen in 1998 and ten in 1999. Time horizons ranged from two to five years. The shortest plan had 2 pages; the longest plan had 59 pages.

Table 1 was used in identifying the stage of integration for each member of the sample. Specifically, for each strategic plan, a copy of the table was filled in by $\mathrm{x}$-marking the most appropriate description for each of the ten integration mechanisms. The scale from 1 (administrative integration) to 4 (full integration) was kept. For example, the researcher found, by studying the plan document for organization A, that the purpose of integration was support and influence of business strategy (3), the role of IS function was resource to support business strategy (2), the primary role of IS executive was formal and integral member of top management who is involved in many business matters (4), performance criteria for IS function was contribution to business strategy implementation (2), triggers for developing IS applications were business goals (2), frequent top management participation in ISP (3), frequent user participation in ISP (3), frequent IS executive participation in business planning (3), infrequent assessment of new technologies (2), and IS executive one level below the CEO (4). Both the researcher and a doctoral student conducted the same coding, and the inter-rater reliability of 0.6 was considered low but acceptable to continue the research. The coding of the researcher is used in data analyses.

Table 2 was used in classifying companies according to their basic value configuration. Companies classified as chains are typically characterized as those transforming input into output, based on a long-linked type of technology. Examples from our sample are manufacturing companies producing food, drugs, paper and pulp. Companies classified as shops are typically characterized as solving (unique) customer problems using intensive technology. Examples of companies in our sample are hospitals, lawyers, and universities. Companies classified as networks are typically characterized by the linking of customers using mediating technologies. Examples of companies in our sample are telecommunications, postal services, insurance companies and banks. As illustrated in Table 4, in our sample 14 companies where classified as value chains, 19 were classified as value shops, and 8 were classified as value networks. 


\begin{tabular}{|c|c|c|c|c|c|}
\hline Company & $\begin{array}{l}\text { Company value } \\
\text { configuration }\end{array}$ & Year & Period & Pages & Document title \\
\hline$A$ & Chain & 1998 & $3-5$ years & 29 & IT STRATEGY \\
\hline $\mathrm{B}$ & Network & \begin{tabular}{|l|}
1999 \\
\end{tabular} & $1999-2004$ & 32 & \begin{tabular}{|l|l|} 
IT STRATEGY \\
\end{tabular} \\
\hline $\mathrm{C}$ & Shop & 1995 & 1995-1999 & 24 & IT STRATEGY \\
\hline $\mathrm{D}$ & Shop & 1999 & To 2002 & 32 & ICT STRATEGY \\
\hline$E$ & Chain & 1999 & $1998-2000$ & 17 & IT STRATEGY \\
\hline $\mathrm{F}$ & Shop & \begin{tabular}{|l|}
1998 \\
\end{tabular} & $1998-2001$ & 59 & IT STRATEGY \\
\hline $\mathrm{G}$ & Chain & 1998 & $1998-2000$ & 25 & IT STRATEGY \\
\hline $\mathrm{H}$ & Chain & 1998 & 1999-2002 & 20 & IT STRATEGY \\
\hline $\mathrm{I}$ & Chain & 1998 & & 14 & IT STRATEGY \\
\hline $\mathrm{J}$ & Chain & 1998 & $1998-2001$ & 30 & IT STRATEGY \\
\hline $\bar{K}$ & Network & 1998 & 1999-2001 & 20 & IT STRATEGY \\
\hline $\mathrm{L}$ & Shop & 1996 & & 47 & PLAN FOR IT \\
\hline$M$ & Network & 1998 & $1998-2000$ & 15 & IT STRATEGY \\
\hline $\mathrm{N}$ & Chain & 1999 & & 2 & IT STRATEGY \\
\hline $\mathrm{O}$ & Chain & 1997 & & 12 & IT STRATEGY \\
\hline $\mathrm{P}$ & Shop & 1999 & 1999-2002 & 18 & IT STRATEGY \\
\hline$Q$ & Chain & 1997 & & 50 & IS STRATEGY \\
\hline $\mathrm{R}$ & Shop & 1995 & 1996-1999 & 41 & IT STRATEGY \\
\hline$S$ & Shop & 1998 & $1998-2001$ & 47 & IT STRATEGY \\
\hline$T$ & Shop & 1999 & 1999-2003 & 21 & PLAN FOR ICT \\
\hline $\bar{U}$ & Shop & 1998 & $1998-2000$ & 40 & IT STRATEGY \\
\hline $\mathrm{V}$ & Chain & 1997 & 1998- & 2 & IT STRATEGY \\
\hline $\mathrm{W}$ & Shop & 1999 & 1999- & 4 & IT STRATEGY \\
\hline $\mathrm{X}$ & Shop & 1998 & 1999-2002 & 13 & IT STRATEGY \\
\hline $\bar{Y}$ & Network & 1998 & 1999- & 9 & IT STRATEGY \\
\hline $\bar{Z}$ & Chain & 1999 & $2000-2002$ & 5 & IT STRATEGY \\
\hline AA & Chain & 1995 & 1996-1999 & 3 & IT STRATEGY \\
\hline $\mathrm{AB}$ & Network & 1993 & 1994-1997 & 30 & IT STRATEGY \\
\hline $\mathrm{AC}$ & Chain & 1998 & 1997-2001 & 11 & IT STRATEGY \\
\hline $\mathrm{AD}$ & Shop & 1998 & $1998-2002$ & 46 & IT STRATEGY PLAN \\
\hline $\mathrm{AE}$ & Network & 1998 & $1998-2001$ & 13 & IT STRATEGY \\
\hline $\mathrm{AF}$ & Shop & 1998 & - & 26 & IT STRATEGY \\
\hline$A G$ & Network & 1997 & $1998-2000$ & 30 & IT STRATEGY \\
\hline $\mathrm{AH}$ & Network & 1998 & 1999-2001 & 11 & IT STRATEGY \\
\hline $\mathrm{Al}$ & Shop & 1998 & - & 4 & IT POLICY \\
\hline AJ & Shop & 1997 & - & 2 & STRATEGY PLAN 1997 \\
\hline $\mathrm{AK}$ & Chain & 1998 & 1999-2001 & 42 & IM STRATEGY \\
\hline $\mathrm{AL}$ & Shop & 1999 & - & 32 & IT STRATEGY PLAN \\
\hline AM & Shop & 1999 & - & 11 & IT STRATEGY \\
\hline AN & Shop & 1997 & $1997-2001$ & 39 & INFORMATION STRATEGY \\
\hline $\mathrm{AO}$ & Shop & 1997 & - & 56 & IT STRATEGY DOCUMENT \\
\hline
\end{tabular}

Table 4: General characteristics of strategic IS/IT plans.

\section{Results}

Assessment of new technology achieves the highest score in Table 5, which means that organizations, in this respect our sample, documents on avarage integration Stage 3 performance. From Table 5 we also see that performance criteria for the IS function achieves the lowest score. Overall, two organizations applied administrative integration, twenty-seven organizations applied sequential integration, eleven organizations applied reciprocal integration while only one organization applied full integration. As we will see later in the discussion of results there are some significant difference among clusters of companies.
The ten integration mechanisms in Table 5 are treated as items on a multiple item scale. The reliability of the scale was measured using Cronbach's alpha. The scale achieves an acceptable reliability of 0.85 . Factor analysis was applied to investigate the existence of more than one scale. Three factors, with eigenvalues greater than 1.0 accounting $71 \%$ of total item differences, were identified as listed in Table 6 . Seven out of ten items load significantly on the same Factor 1, which we have called objectives. Status of the IS executive (Factor 2), measured by the number of levels below the CEO, does not seem related to the other integration mechanisms since it loads on a separate factor. User participation (Factor 


\begin{tabular}{|c|c|c|c|c|c|c|c|c|c|c|c|}
\hline Integration Mechanism & M. & s.d. & 1 & 2 & 3 & 4 & 5 & 6 & 7 & 8 & 9 \\
\hline 1 Purpose of integration & 2.1 & 8 & & & & & & & & & \\
\hline 2 Role of IS function & 2.0 & .9 & $.79^{* *}$ & & & & & & & & \\
\hline 3 Primary role of IS executive & 2.0 & .9 & $.67^{* *}$ & $.78^{\star \star}$ & & & & & & & \\
\hline 4 Performance criteria for IS function & 1.7 & .9 & $.46^{* *}$ & $.60^{\star *}$ & $.54^{\star *}$ & & & & & & \\
\hline 5 Triggers for developing IS applications & 2.0 & .8 & $.80^{* *}$ & $.69^{\star \star}$ & $.52^{\star \star}$ & $.61^{* *}$ & & & & & \\
\hline 6 Top management participation in ISP & 2.1 & .8 & $.40^{* *}$ & $.48^{\star \star}$ & $.49^{\star \star}$ & $.35^{*}$ & $.35^{*}$ & & & & \\
\hline 7 User participation in ISP & 2.6 & .6 & .17 & .09 & .08 & -.03 & 13 & .03 & & & \\
\hline 8 IS executive participation in BP & 1.9 & .8 & $.44^{\star *}$ & $.46^{\star \star}$ & $.58^{\star \star}$ & $.48^{\star \star}$ & $.46^{\star *}$ & $.48^{* \star}$ & .04 & & \\
\hline 9 Assessment of new technology & 2.7 & .7 & $.38^{*}$ & $.49^{\star *}$ & .23 & .07 & .28 & .19 & .21 & .18 & \\
\hline 10 Status of IS executive & 2.6 & .6 & .11 & .22 & .29 & .16 & .07 & $.48^{* *}$ & .01 & .25 & $.44^{* *}$ \\
\hline
\end{tabular}

Note: statistical difference is significant at $\mathrm{p}<0.05$ at $*$ and $\mathrm{p}<0.01$ at $* *$.

Table 5: Summary statistics.

\begin{tabular}{|c|c|c|c|}
\hline Integration Mechanism & $\begin{array}{l}\text { Factor 1: Objec- } \\
\text { tives }\end{array}$ & Factor 2: $\mathrm{ClO}$ & Factor 3: Users \\
\hline 1 Purpose of integration & $\begin{array}{r}.842 \\
\end{array}$ & -.203 & 271 \\
\hline 2 Role of IS function & 897 & $-7.383 \mathrm{E}-02$ & .122 \\
\hline 3 Primary role of IS executive & 835 & $-5.526 \mathrm{E}-02$ & $-9.619 \mathrm{E}-02$ \\
\hline 4 Performance criteria for IS function & .699 & -.325 & -.240 \\
\hline 5 Triggers for developing IS applications & .798 & -.327 & .181 \\
\hline 6 Top management participation in ISP & .637 & .307 & -.363 \\
\hline 7 User participation in ISP & .144 & .172 & .737 \\
\hline 8 IS executive participation in BP & .684 & $-2.506 \mathrm{E}-02$ & -.284 \\
\hline 9 Assessment of new technology & .465 & .573 & .417 \\
\hline 10 Status of IS executive & .383 & .786 & -.281 \\
\hline
\end{tabular}

Note: Extraction Method: Principal Component Analysis, 3 components extracted.

Table 6: Component matrix based on factor analysis.

\begin{tabular}{|l|c|c|c|c|c|c|}
\hline Integration Mechanisms & Chain & Shop & Network & $\begin{array}{c}\text { Network } \\
- \text {-Chain }\end{array}$ & $\begin{array}{c}\text { Net- } \\
\text { work- } \\
\text { Shop }\end{array}$ & $\begin{array}{c}\text { Chain } \\
\text {-Shop }\end{array}$ \\
\hline 1 Purpose of integration & 2.3 & 1.9 & 2.4 & .22 & 1.17 & 1.35 \\
\hline 2 Role of IS function & 2.1 & 1.7 & 2.6 & 1.36 & $2.50^{* *}$ & 1.34 \\
\hline 3 Primary role of IS executive & 2.4 & 1.6 & 2.3 & -.26 & $2.12^{*}$ & $2.52^{* *}$ \\
\hline 4 Performance criteria for IS function & 1.9 & 1.4 & 2.1 & .41 & $2.46^{*}$ & $2.01^{*}$ \\
\hline 5 Triggers for developing IS applications & 2.2 & 1.8 & 2.3 & .10 & 1.34 & $1.71^{*}$ \\
\hline 6 Top management participation in ISP & 2.2 & 1.9 & 2.3 & .10 & .89 & .96 \\
\hline 7 User participation in ISP & 2.4 & 2.8 & 2.5 & .26 & -1.28 & $-1.75^{*}$ \\
\hline 8 IS executive participation in BP & 1.9 & 1.7 & 2.1 & .83 & 1.21 & .43 \\
\hline 9 Assessment of new technology & 2.4 & 2.7 & 3.0 & $2.14^{*}$ & .84 & -1.56 \\
\hline 10 Status of IS executive & 2.6 & 2.7 & 2.6 & .20 & -.22 & -.49 \\
\hline
\end{tabular}

Note: statistical difference is significant at $\mathrm{p}<0.05$ at $*$ and $\mathrm{p}<0.01$ at $* *$.

Table 7: Differences between value configurations in stages of integration.

3) also seems independent from other integration mechanisms since it loads on a separate factor.

Using the conceptual framework of three different value configurations (Stabell and Fjeldstad 1998), the sample was clustered into chain, shop, and network. Applying a t-test shows that there are some significant differences among the different clusters. Table 7 provides the item means for the three clusters and the significance numbers of an independent sample test. The results for the three-cluster comparison of means are shown graphically in Figure 1. Members of the shop cluster seem to take a more conservative stance than members of the other two clusters chain and network. One exception is Variable 7, users participation in ISP, where shops scores relatively high compared with the other two clusters. Table 7's means for chain and networks are pretty much equal, except for Variable 9, assessment of new technology, which indicates more frequent assessment for networks. 


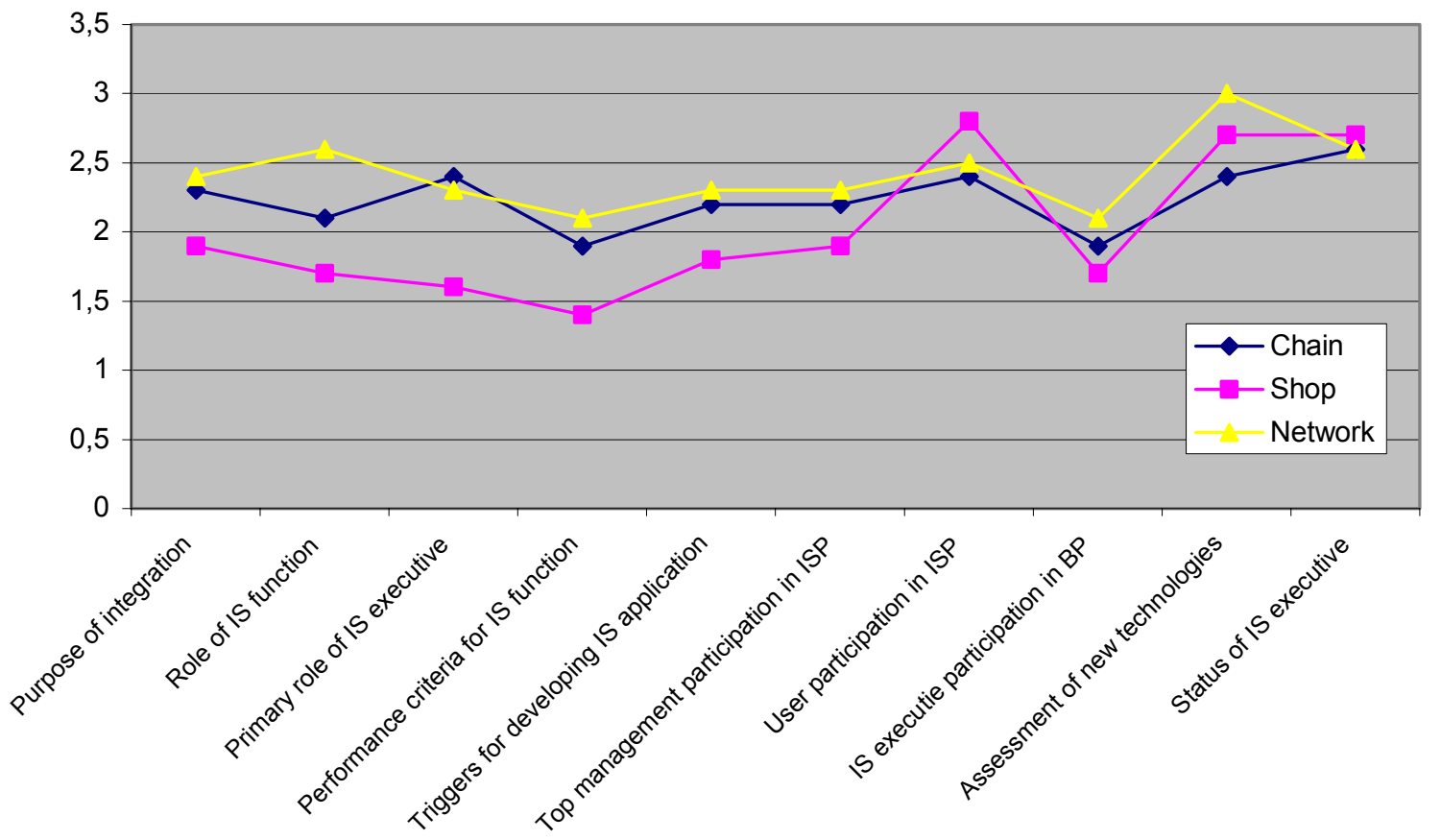

Figure 1: Three cluster comparison of means.

Our propositions can now be tested using the results in Table 7. We proposed that networks would have a higher level of integration between business planning and information systems planning than value chains or shops. We find only partial support for this proposition. Only one significant difference, concerning Variable 9, assessment of new technology, was identified between networks and chain. Value networks in our sample conduct assessment of new technology more frequently than value chains. Three significant differences were identified between networks and shops. Value networks have IS functions that support and influence business strategy, while value shops have IS functions that only support business strategy. In addition, networks are at a higher stage concerning the primary role of the IS function, and the performance criteria for the IS function. With respect to the second proposition, that looks at differences between chain and shop, four significant differences were identified concerning Variables 3, 4, 5, and 7. Value chains are at a higher stage concerning the primary role of IS executive, performance criteria for IS function, and triggers for developing IS applications. However, value shops are at a higher stage than value chains concerning user participation in ISP, which is an interesting contraction of the second proposition.
Another way to test the propositions is to use the main factor, objectives, from Table 6 . The factor consisted of seven out of ten integration mechanisms. Averages for this factor were computed for all responding organizations, and a significant difference was found between networks and shops $(\mathrm{t}=2.2$, $\mathrm{p}<0.05, \mathrm{df}=25)$ and between chains and shops $(\mathrm{t}=2.0, \mathrm{p}<0.05$, $\mathrm{df}=31$ ). In conclusion, proposition 1 is confirmed regarding networks versus shops: Value networks are more likely than value shops to facilitate integration between BP and ISP. Proposition 2 is confirmed regarding chains versus shop: Value chains are more likely than value shops to facilitate integration between BP and ISP. However, Table 7 indicates that there is no complete support for these propositions.

\section{Discussion}

Typically, value chains transform input into output (products) using a long-linked technology. Scale and capacity utilization are key cost drivers. For each basic activity in the business value system the effort of IS is to improve products and production processes. Information systems are developed to support the activities in the value chain: accounting systems, production planning and control systems, marketing and sales systems. A typical example of administrative integration be- 
tween BP and ISP was plan E in Table 4 for a food producer: IT can assist business processes in realizing and exploiting solutions for value creation. Value chains belong to the IT era as indicated by their technology use and stage of planning integration.

Value shops rely on an intensive technology to solve a customer or client problem. Selection, combination, and order of application of resources and activities vary according to the problem at hand. The development and use of IS, such as diagnostics, simulations, project management tools, and collaborative technologies, is first of all to support or assist the solution of unique problems. A typical example of administrative integration between BP and ISP was plan S in Table 4 for a municipal health and social sector: Our goal is for all health personnel to use IT as help in medical and administrative matters better than before. Value shops belong to the DP era as indicated by their technology use and stage of planning integration.

Value networks rely on a mediating technology to link clients or customers who are or wish to be interdependent. The mediating technology facilitates exchange relationships among customers distributed in time and space. Technology development is basically a support activity, but technology may as well be core business in this value configuration. The growing convergence of telecommunications, computing and production technology is of special relevance for value networks. Development and use of IS might be to obtain operational efficiency and cost minimization, as well as to create new integrated services or products. A typical example of reciprocal/full integration between BP and ISP was plan AG in Table 4 for a telecommunication company: Business puts heavy demands on IT, as IT contributes heavily to new business. Value networks belong to the IT network era as physical and electronic networks converge towards each other.

\section{Conclusion}

Integration between business planning and information systems planning was investigated in this research using four integration stages and ten integration mechanisms suggested by King and Teo (1997). Clustering of organization was done using the conceptual framework of Stabell and Fjeldstad (1998). Overall, the results lead to two conclusions: (1) there are identifiable clusters among the organizations, and (2) the nature of the clusters shows some significant differences. However, the results are not robust enough to suggest any universal concept of the role of IS in different value configuration.

Knowing that this research was unable to look into the companies' business plans, this could be an interesting topic for further research. Are we able to find the same evidence by studying business plans? Will future research experience that it is easier to get IS plans rather than business plans? Another approach could be to interview selected business planners and check if our assumptions are correct.

\section{References}

Beattie, K. R. and A. M. Sohal (1999). "Implementing ISO 9000: A study of its benefits among Australian organizations." Total Quality Management 10(1): 95-106.

Broadbent, M. and P. Weill (1993). "Improving business and information strategy alignment: Learning from the banking industry." IBM Systems Journal 32(1): 162-179.

Crouch, A. and J. Basch (1997). "The Structure of Strategic Thinking: a lexical and content analysis." Journal of Applied Management Studies 6(1): 13-34.

Das, S. R., S. A. Zahra, et al. (1991). "Integrating the Content and Process of Strategic MIS Planning with Competitive Strategy." Decision Sciences 22(1): 953-984.

Earl, M. J. and D. F. Feeny (1994). "Is Your CIO Adding Value?" Sloan Management Review 35(3): 11-20.

Henderson, J. C. and N. Venkatraman (1993). "Strategic alignment: Leveraging information technology for transforming organizations." IBM Systems Journal 32(1): 4-16.

Holsti, O. R. (1969). Content Analysis for the Social Sciences and Humanities. USA, Addison-Wesley Publishing.

Khandelwal, V. K. and J. Ferguson (1999). Critical Success Factors (CSFs) and the Growth of IT in Selected Geographic Regions. Proceedings of 32nd Hawaii International Conference on Systems Sciences (HICSS-32), January 5-8, USA: Maui.

King, W. and T. S. H. Teo (1997). "Integration Between Business Planning and Information Systems Planning: Validating a Stage Hypothesis." Decision Science 28(2): 279-308.

Krippendorff, K. (1980). Content Analysis: An Introduction to Its Methodology, Sage Publications.

Lederer, A. L. and A. L. Mendelow (1989). "Coordination of information systems plans with business plans." Journal of Management Information Systems 6(2): 5-19.

Lee, A. S. (1991). "Integrating positivist and interpretive approaches to organizational research." Organization Science 2(4): 342-365.

Luftman, J. N., R. Papp, et al. (1999). "Enablers and inhibitors of business-IT alignment." Communications of AIS 1(March).

Miles, M. B. and A. M. Huberman (1994). Qualitative data analysis: an expanded sourcebook. USA: Thousand Oaks, SAGE Publications. 
Differences in Stage of Integration

Mintzberg, H. (1994). The Rise and Fall of Strategic Planning, Prentice Hall Europe.

Naccarato, J. L. and K. A. Neuendorf (1998). "Content Analysis as a Predictive Methodology: Recall, Readership, and Evaluations of Business-to-Business Print Advertising." Journal of Advertising Research(May - June): 19-33.

Nolan, R. L. (1973). "Managing the computer resource: A stage hypothesis." Communications of the ACM 7: 399-405.

Porter, M. E. (1985). Competitive Advantage: Creating and Sustaining Competitive Performance, The Free Press.

Riffe, D. and A. Freitag (1997). "A Content Analysis of Content Analyses: Twenty-Five Years of Journalism Quarterly." Journalism \& Mass Communication Quarterly 74(3): 515-524.

Stabell, C. B. and Ø. D. Fjeldstad (1998). "Configuring Value for Competitive Advantage: On Chains, Shops and Networks." Strategic Management Journal 19: 413-437.
Teo, T. S. H. and J. S. K. Ang (1999). "Critical success factors in the alignment of IS plans with business plans." International Journal of Information Management 19: 173-185.

Teo, T. S. H. and W. R. King (1997). "Integration between Business Planning and Information Systems Planning: An EvolutionaryContingency Perspective." Journal of Management Information Systems 14(1): 185-214.

Thompson, J. D. (1967). Organizations in action, McGraw-Hill.

Weber, R. P. (1990). Basic Content Analysis, Sage Publications.

Woolfe, R. (1993). "The path to strategic alignment." Information Strategy: The Executive's Journal: 13-23.

Yin, R. K. (1994). Case Study Research: Design and Methods. Thousand Oaks, CA, Sage Publications. 